\title{
Effects of electromagnetic radiation exposure on bone mineral density, thyroid, and oxidative stress index in electrical workers
}

\author{
Halil Kunt ${ }^{1, *}$ \\ İhsan Șentürk2,* \\ Yücel Gönül $\left.\right|^{3, *}$ \\ Mehmet Korkmaz ${ }^{4}$ \\ Ahmet Ahsen ${ }^{5}$ \\ Ömer Hazman ${ }^{6}$ \\ Ahmet Bal ${ }^{7}$ \\ Abdurrahman Genç ${ }^{8}$ \\ Ahmet Songur ${ }^{3}$ \\ 'Department of Science Education, \\ Faculty of Education, Dumlupınar \\ University, Kütahya, ${ }^{2}$ Department \\ of Orthopedics and Traumatology, \\ ${ }^{3}$ Department of Anatomy, Faculty of \\ Medicine, Afyon Kocatepe University, \\ Afyonkarahisar, ${ }^{4}$ Department of \\ Radiology, Faculty of Medicine, \\ Dumlupınar University, Kütahya, \\ ${ }^{5}$ Department of Nephrology, Faculty \\ of Medicine, ${ }^{6}$ Department of \\ Biochemistry, Faculty of Science and \\ Arts, ${ }^{7}$ Department of General Surgery, \\ ${ }^{8}$ Department of Physiology, Faculty of \\ Medicine, Afyon Kocatepe University, \\ Afyonkarahisar, Turkey
}

*These authors contributed equally to this work

Correspondence: Yücel Gönül Department of Anatomy, Faculty of Medicine, Afyon Kocatepe University, Ali Çetinkaya Kampusü-Izmir Karayolu 8.km, 03200-Afyonkarahisar, Turkey

Tel +90 50557 I 5259

Fax +90272 2463300

Email yucel94@hotmail.com
This article was published in the following Dove Press journal:

OncoTargets and Therapy

12 February 2016

Number of times this article has been viewed

Background: In the literature, some articles report that the incidence of numerous diseases increases among the individuals who live around high-voltage electric transmission lines (HVETL) or are exposed vocationally. However, it was not investigated whether HVETL affect bone metabolism, oxidative stress, and the prevalence of thyroid nodule.

Methods: Dual-energy X-ray absorptiometry (DEXA) bone density measurements, serum free triiodothyronine (FT3), free thyroxine (FT4), RANK, RANKL, osteoprotegerin (OPG), alkaline phosphatase (ALP), phosphor, total antioxidant status (TAS), total oxidant status (TOS), and oxidative stress index (OSI) levels were analyzed to investigate this effect.

Results: Bone mineral density levels of L1-L4 vertebrae and femur were observed significantly lower in the electrical workers. ALP, phosphor, RANK, RANKL, TOS, OSI, and anteroposterior diameter of the left thyroid lobe levels were significantly higher, and OPG, TAS, and FT4 levels were detected significantly lower in the study group when compared with the control group.

Conclusion: Consequently, it was observed that the balance between construction and destruction in the bone metabolism of the electrical workers who were employed in HVETL replaced toward destruction and led to a decrease in OPG levels and an increase in RANK and RANKL levels. In line with the previous studies, long-term exposure to an electromagnetic field causes disorders in many organs and systems. Thus, it is considered that long-term exposure to an electromagnetic field affects bone and thyroid metabolism and also increases OSI by increasing the TOS and decreasing the antioxidant status.

Keywords: bone mineral density, electromagnetic radiation, electrical workers, thyroid, RANK, RANKL

\section{Introduction}

Electromagnetic field (EMF) is a space of mobile and electric-loaded particles affected by power and appears as a result of spinning of the electrons inside atoms around the atomic core and themselves. ${ }^{1}$ Human body acts like an electromagnetic machine where each cell has a specific electric circuit. ${ }^{2}$ Therefore, human being has a magnetic field. The magnetic field in the human body appears by the movements of bioelectrical loads, and the magnetic field signals of the substances creating human to intercommunicate are consistent with each other. Alongside the internal and external magnetic field existing in the nature, human beings are exposed to some magnetic fields such as cell phones, computers, electrical household appliances, and high-voltage transmission lines. The electromagnetic balance of the human body is disrupted by these magnetic fields. ${ }^{2}$ 
EMFs reach into the tissues, causing cellular dysfunctions. ${ }^{3}$ They lead to disorders such as insomnia, headache, and stress. These fields negatively affect blood biochemistry, digestive and circulatory systems, and increase the risk for cancer. ${ }^{4-8}$ High-voltage transmission lines were detected as a cause for leukemia and brain cancer in children; and a close relation between childhood cancers, especially leukemia and living in close proximity to high-voltage electric transmission lines were observed. ${ }^{8,9}$ Studies conducted in the USA and Finland determined that Alzheimer's disease is observed four times more in men and three to four times more in women among the workers (radio operators, industrial equipment workers, data processing device mechanics, phone-line workers, those working in electric plants, and substations) who are frequently exposed to EMFs. ${ }^{2}$

Since a magnetic field is not visible, not directly sensed, and the effects are observed cumulatively after a long period, it is not regarded enough. Although, it is still problematic whether a poor magnetic field is harmful for human health, studies carried out on animal cells revealed that poor magnetic field causes many biological effects such as changing hormone and enzyme levels, preventing motion of tissue chemicals..$^{10-15}$ In the literature, some articles report that the incidence of numerous diseases increases among the individuals who live around high-voltage electric transmission lines (HVETL) or are exposed vocationally. ${ }^{16-18}$ However, it was not investigated that whether HVETL affect the bone metabolism, prevalence of the thyroid nodule, and oxidative stress levels in electrical workers. Furthermore, since biological effects of EMF are observed after a long period, the electrical workers are an appropriate group to search this effect. In the present study, we examined the effects of exposure to an EMF on bone mineral density (BMD), thyroid nodule formation, serum free triiodothyronine (FT3), free thyroxine (FT4), RANK, RANKL, osteoprotegerin (OPG), alkaline phosphatase (ALP), phosphor (P) levels, total antioxidant status (TAS), total oxidant status (TOS), and oxidative stress index (OSI) of electrical workers.

\section{Patients and methods}

The study group included 47 electrical workers employed in Electricity Generation Company (EGC) Transmission-Operation Facility 6, Kütahya and their ages varied between 29 and 52 years (mean 38.4 years). Mean working period of the study group was determined as $15.9 \pm 6.72$ years. The control group was created from 47 healthy individuals with a similar socio-economical status with an age range between 28 and 52 years (mean 39.1 years) who were not exposed to ionizing and non-ionizing radiation for diagnostic and therapeutic purposes and who complied with the study group in terms of smoking and exercise habits. Consent of Clinical Researches Ethics Committee of Afyonkarahisar with a consent number of 2012/15-123 was obtained on July 6, 2012. This study was supported by Afyon Kocatepe University Scientific Research Projects Unit (Project no: 12.TIP.11).

The participants of the study were informed and their written consent was obtained. Individuals who work as electrical workers at least for 10 years were enrolled for this study. Individuals working for less than 10 years were excluded. Individuals without diseases that may affect the bone metabolism (thyroid/parathyroid disorders, kidney failure, autoimmune or tumoral diseases) and those who do not have the aforesaid conditions in their medical history were enrolled for this study. The participants were investigated for osteoporosis factors such as body mass index, smoking, alcohol use, nutritional status, familial medical history, and exercise and exposure to EMF including use of cell phones, computer, and hair dryer. The participants did not expose to any radiation such as magnetic resonance imaging (MRI) for diagnosis and treatment purposes. Furthermore, all the participants were informed about the study and told the minimal risk of radiation absorption related to the dual-energy X-ray absorptiometry (DEXA) scans and, included in the study after their consent was received. The data about the familial and personal medical history, dietary habits, exercise and physical activity status, and the conditions such as fatigue, anxiety, and headache after work were obtained through a face-to-face survey including 34 questions. Furthermore, the measurements of EMF and body temperatures of the electrical workers were performed in their units. Blood analyses, ultrasound scan (USS) of the thyroid gland, and bone DEXA scan of the participants were used as a tool for data collection.

\section{USS of the thyroid gland}

USS of the thyroid gland was performed in the control and the study group. The scan was performed with a LOGIQ 7 (General Electric Medical System, Milwaukee, WI, USA) ultrasonography device through a 7.5-10 MHz linear probe. The procedure was applied after positioning the patient's neck to extension by placing a lifter under the patient's shoulder. During the scan, images on the coronal, horizontal, and sagittal planes were obtained and thyroid gland size, homogeneity of the thyroid parenchyma echo, the presence of the nodule (present-absent), and vascularity through Doppler ultrasonography were assessed.

\section{DEXA measurements}

BMD of the lumbar area and hip of the individuals in both groups were measured by using the DEXA method (DXA. 
Hologic QDR 4500) and the lowest t-score value was used for statistical evaluation. Baltas et al mentioned that the DEXA method was approved by WHO (World Health Organization), NOF (National Osteoporosis Foundation), and IOF (International Osteoporosis Foundation) for diagnosis and follow-up of osteoporosis, ${ }^{19}$ and it is an essential tool to measure the BMD. The measures of the lumbar vertebra and femur are accepted as general measurement areas for the diagnosis of osteopenia and osteoporosis. It is a routine method for BMD. In the present study, the DEXA method was utilized to measure BMD and measures of the lumbar vertebrae and femur were performed.

T-score shows the difference of BMD scores between the patient and young adults who have the same sex and ethnicity with the patient. T-score values of the groups were used in the study.

(Hip) BMD measurement: While the patient was lying on supine position on the table, her/his feet were positioned on internal rotation by $25^{\circ}$ with a $30 \mathrm{~cm}$ gap between the feet and fixed in a foot positioner. Hip joint, femur head, and femur neck were included into the screening.

(L1-L4) BMD measurement: The patient was positioned on supine position and full contact of the waist was provided by placing a support under the knees. Vertebrae between L1 and L4 were taken into the shot.

\section{Biochemical analyses Analyses of bone metabolism parameters (OPG, RANK, RANKL)}

Blood analyses were performed by collecting venous blood samples of the patients with an empty stomach; and serum levels of three different parameters including OPG (e-Bioscience, Vienna, Austria), RANK (Cusabio, Wuhan, Hubei, People's Republic of China), and RANKL (BioVendor, Shenzhen, People's Republic of China) were analyzed by an ELISA device (Biotek ELx800) in accordance with human-specific kit protocols. During the ELISA analysis, the standards procured with the kits were thawed, then diluted. Eight standards were prepared to create the calibration curve required for calculating the concentrations in ELISA device automatically by using the absorbance of the samples. Standards and samples were analyzed twice, and the mean value of each standard and sample was used for statistical calculations.

The kits used include OPG (e-Bioscience), Ref no: BM2021INST, Lot no: 74889021; RANK (Cusabio) Catalog no: CSB-E13539h, Lot no: F15069918; RANKL (BioVendor) Ref no: RD193004200R, Lot no: E12-054.

\section{Analysis of thyroid functions}

All tests were analyzed in the same laboratory. Serum concentrations of thyroid-stimulating hormone (TSH), FT3, and FT4 were analyzed with the original kits of Abbott Architect 1600 Chemiluminescence method.

\section{Analysis of TAS and TOS}

Methods such as TAS to measure the antioxidant status in a medium are generally calibrated by using a standard antioxidant solution called Trolox Equivalent which is analogous of vitamin E; the TAS levels measured were read as mmol Trolox Equiv/L. TAS measurements were performed by kinetic reading in the spectrophotometer 5 minutes after the sample and reagent were mixed. TOS measurements were done by reading at end-point $560 \mathrm{~nm}$ in the spectrophotometer 3-4 minutes after mixing the samples and reagents, and the results were expressed in hydrogen peroxide liter $\left(\mu \mathrm{mol} \mathrm{H}_{2} \mathrm{O}_{2}\right.$ equiv/L).

\section{Calculation of OSI}

After TAS and TOS measurements, the OSI levels, which allow us to make an exact comment on the oxidant and antioxidant balance, were calculated according to the following formula specified in the catalog of the kit (rel assay diagnostics). OSI $=($ TOS $\mu \mathrm{mol} / \mathrm{L}) /($ TAS $[\mathrm{mmol}$ Trolox Equiv/L] $\times 100)$.

\section{Statistical analysis}

The data of the individuals who were exposed to the magnetic field and consisted of healthy individuals as the control group were analyzed by SPSS for Windows 15.0 package program of statistics. Compliance of the data to normal distribution was investigated by the Kolmogorov-Smirnov test. The analysis of the data compliant to the normal distribution was performed by independent sample $t$-test and one-way analysis of variance (ANOVA) for comparisons between the groups. The Least Significant Difference (LSD) test was used to determine the source of the statistically significant difference as a result of ANOVA test. Paired comparisons between the groups for the data that are not compliant with normal distribution were performed through Mann-Whitney $U$-test. The chi-square test was used for the comparison of the qualitative data. As a result of the analysis, $P$-values smaller than 0.05 were accepted as statistically significant.

\section{Results}

Age average and mean working period of the electrical workers were determined as 38.4 years and 15.9 years, respectively; age average and mean working period of the control group were 39.1 years and 17.2 years, respectively. 
Table I The characteristics of the groups

\begin{tabular}{lll}
\hline Patient features and EMA exposure & Control Group $(\mathbf{n = 4 7})$ & Study Group $(\mathbf{n = 4 7 )}$ \\
\hline Age (years) & & $38.37 \pm 7.53$ \\
$\quad$ Average age* & $39.05 \pm 5.85$ & $29-52$ \\
$\quad$ Minimum/maximum age & $28-52$ & $15.89 \pm 6.72$ \\
Work experience (years)* & $17.21 \pm 6.64$ & $18 / 47$ \\
Smoking & $1 \mathrm{l} / 47$ & $26.21 \pm 4.67$ \\
Body Mass Index $\left(\mathrm{kg} / \mathrm{m}^{2}\right)^{*}$ & $26.65 \pm 4.16$ & $36.92 \pm 5.6 \mathrm{I}$ \\
Body temperature measurements $\left({ }^{\circ} \mathrm{C}\right)^{*}$ & $36.73 \pm 5.14$ & $34 / 47$ \\
Fatigue, anxiety and headaches & $16 / 47$ & $0.53 \pm 0.25$ \\
The average measurement of HVETL exposure $(\mu \mathrm{TT})^{*}$ & $\mathrm{~N} / \mathrm{A}$ & $504.55 \pm 7.69$ \\
Mobile phone usage time* & $537.46 \pm 8.47$ & $1.1 \pm 0.77$ \\
(minutes/month) & & $21.82 \pm 4.22$ \\
Hair dryer (times/week)* & $1.6 \pm 0.6 \mathrm{I}$ & \\
Computer use (hours/week)* & $23.33 \pm 5.6 \mathrm{I}$ & \\
\hline
\end{tabular}

Note: *The data is given as mean \pm standard deviation.

Abbreviations: EMA, electromagnetic area; HVETL, high-voltage electric transmission lines; N/A, not applicable.

Age average and mean working period of the study and control group were consistent with each other. Smoking, exhaustion, anxiety, and headache were found lower, whereas the use of cell phone, computer, and hair dryer was found higher in the control group. Body mass indexes were comparable between both groups (Table 1).

No significant difference was observed between the groups in terms of the dietary habits and physical activity $(P>0.05)$. In the evaluation of the nutritional habits in the participants, weekly consumption of protein, milk, yogurt, and vegetables were found to be similar. In addition, alcohol addiction, salt habits, and activity levels were found to be quite low, moderate, and low, respectively (Table 2).

Table 2 Nutrition and habits of the participants

\begin{tabular}{|c|c|c|}
\hline Feature & $\begin{array}{l}\text { Experimental } \\
\text { group }\end{array}$ & $\begin{array}{l}\text { Control } \\
\text { group }\end{array}$ \\
\hline Smoking & $15 / 47$ & $1 \mathrm{I} / 47$ \\
\hline Alcohol consumption & $5 / 47$ & $5 / 47$ \\
\hline \multicolumn{3}{|l|}{ Salt consumption } \\
\hline Salt-free & 0 & 0 \\
\hline Low salty & 6 & 3 \\
\hline Moderate salty & 43 & 37 \\
\hline High salty & 0 & 0 \\
\hline \multicolumn{3}{|l|}{ Coffee consumption (cups/day) (n) } \\
\hline None & 0 & 4 \\
\hline I & 44 & 39 \\
\hline 2 and over & 3 & 4 \\
\hline \multicolumn{3}{|l|}{ Milk consumption (glasses/week) (n) } \\
\hline $\mathrm{I}-4$ & 43 & 42 \\
\hline $5-8$ & 4 & 5 \\
\hline Type of Nutrition & Mixed & Mixed \\
\hline \multicolumn{3}{|l|}{ Exercise and sports activity within the last } \\
\hline \multicolumn{3}{|l|}{5 years; } \\
\hline $\begin{array}{l}\text { Sport such as walking and weight lifting at } \\
\text { least } 3 \text { times per week on a regular basis. }\end{array}$ & 3 & 5 \\
\hline
\end{tabular}

In bone DEXA scans, mean BMD of L1-L4 was found $-1.13 \mathrm{~g} / \mathrm{cm}^{2}$ in the study group and $-0.16 \mathrm{~g} / \mathrm{cm}^{2}$ in the control group. Similarly, BMD of femur was found $-63 \mathrm{~g} / \mathrm{cm}^{2}$ and $0.31 \mathrm{~g} / \mathrm{cm}^{2}$ in the study and control group, respectively. A significant difference was observed between BMD measurements of lumbar vertebrae L1-L4 and femur $(P<0.05)$. Additionally, a significant difference was found between ALP and P levels $(P<0.05)$. Mean ALP values in the control group and the study group were found as 76.00 versus $88.04 \mathrm{U} / \mathrm{L}$, respectively. Blood phosphorus levels were in the control group, and the study group detected as 2.80 versus $3.43 \mathrm{mg} / \mathrm{dL}$, respectively. RANK, RANKL, and OPG levels seem to support a possible increase for tendency to a severe osteoporosis in the individuals working around HVETL $(P<0.001, P<0.001$, and $P=0.004$, respectively) (Table 3, Figures 1-3).

Although thyroid function tests (FT3 and TSH) were lower in the study group, they were not statistically significant. The FT4 level was detected significantly lower in the study group than the control group. Furthermore, anteroposterior diameter measures of the thyroid gland of the study group increased when compared with the control group according to the morphometric measurement by USS; however, the result was not statistically significant. Left anteroposterior diameter measure of the thyroid gland was found significantly higher in the study group $(P<0.05)$. There was not any significant difference between the groups in terms of nodule and parenchyma (Table 4).

Mean BMD values of L1-L4 and femur according to the age were detected lowest in 20-29 years of age and highest in 30-39 years of age in bone DEXA measurements. No significant difference was observed between BMD measurements of L1-L4 of the lumbar vertebrae and femur (Table 5). 
Table 3 Comparison of bone mineral density and blood chemistry parameters between the study and control group

\begin{tabular}{|c|c|c|c|}
\hline Measured parameters & Control group & Study group & $P$-value \\
\hline RANK (pg/mL) & $82.24(4.63-263.27)$ & I02.2| (48.63-294.84) & $P<0.00$ \\
\hline RANKL (pmol/L) & $322(\mid 12-1,272)$ & $408.06(191-1,262)$ & $P<0.00 I^{*}$ \\
\hline OPG (pg/mL) & $51.98(29.54-107.22)$ & $45.06(25.35-83.85)$ & $P=0.004^{*}$ \\
\hline BMD (LI-L4) & $-0.16 \pm 0.93$ & $-1.13 \pm 0.99$ & $P<0.05$ \\
\hline BMD (FEMUR) & $0.3 \mathrm{I} \pm 1.00$ & $-0.63 \pm 0.84$ & $P<0.05$ \\
\hline $\mathrm{ALP}(\mathrm{U} / \mathrm{L})$ & $76.00 \pm|9.7|$ & $88.04 \pm 22.25$ & $P<0.05$ \\
\hline$P(\mathrm{mg} / \mathrm{dL})$ & $2.80 \pm 0.41$ & $3.43 \pm 0.37$ & $P<0.05$ \\
\hline
\end{tabular}

Notes: *Mann-Whitney $U$-test was used for binary comparisons between groups in these data, and the values were given as median (minimum-maximum). $t$-test (independent samples $t$-test) for independent samples was applied in other data and values were given as mean \pm standard deviation.

Abbreviations: OPG, osteoprotegerin; BMD, bone mineral density; ALP, alkaline phosphatase; P, phosphor.

Depending on the work experience, BMD values of L1-L4 and femur of the electrical workers with work experience of 20 years and over were found higher than those working for 10-19 years in both measurements. There was not any significant difference observed between BMD measurement levels of L1-L4 lumbar vertebrae, whereas a significant difference was observed between BMD levels of femur $(P<0.05$; Table 6$)$.

Due to the work experience, Ca, ALP, RANK, and RANKL values of L1-L4 and femur of the electrical workers with work experience of 20 years and over were found higher than those working for 10-19 years. No significant difference was observed between values of $\mathrm{Ca}$, RANK, and RANKL and a significant difference was detected between serum ALP values $(P<0.05)$ (Table 7).

A significant elevation in the OSI and a significant reduction of total oxidative stress were found in the study group. These findings suggest that EMF increases the TOS, decreases the antioxidant status, and causes oxidative stress damage in the electrical workers $(P<0.05)$ (Table 8$)$.

\section{Discussion}

Electromagnetic waves (EMWs) damage tissues of the body through heating and changing chemical reactions. ${ }^{20}$ High

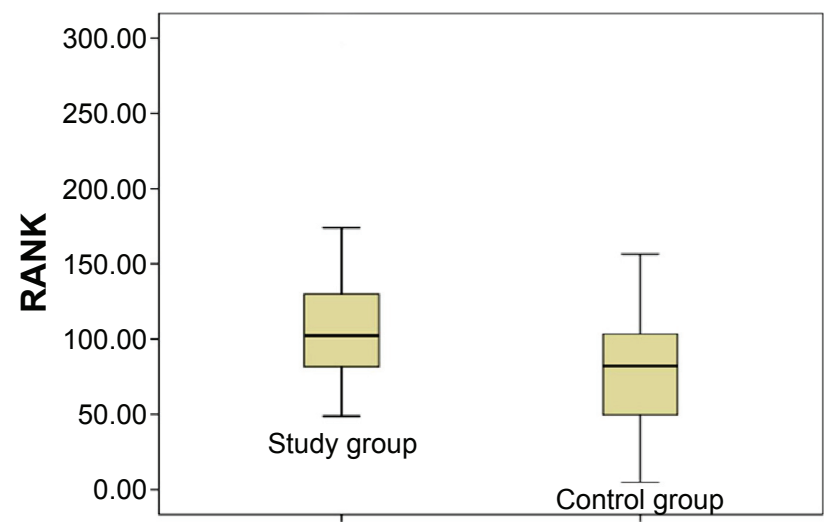

Figure I Distribution of RANK values in the study and control groups.
EMWs cause damage by heat; hazardous effects appear on the tissues by long-term exposure to low EMWs because of chemical changes. Some energy spreaded by EMW due to the heat effect is absorbed by the human body, and heat accumulation occurs inside the body. Such heat may cause undesired outcomes. The second effect is disruption of the molecules and atoms which are bonded to each other in a living organism. ${ }^{20}$

The limit of professional exposure is $500 \mu \mathrm{T}$ for a magnetic field. ${ }^{21}$ The highest exposure was found on electrical workers by a mean value of $0.161 \mu \mathrm{T}$ in the studies conducted on different occupational groups. ${ }^{22}$ Despite the fact that no measurements could be performed in the substation areas because of security measures and risk of accident, mean daily exposure was found $0.53 \mu \mathrm{T}$ in the EMF measurements carried out on the workplaces and walking areas. Exposure to an EMF increases sodium, calcium, and magnesium levels in the plasma ${ }^{23}$ and the oxidative stress. ${ }^{15}$ Studies carried out with a Guinea pig showed that exposure to an EMF causes a significant increase in oxidant products and a decrease in antioxidant enzyme activity. ${ }^{13}$ The studies assessing the exposure level generally detected that the exposure at $0.4 \mu \mathrm{T}$ and above increases the risk of leukemia during childhood. ${ }^{24,25}$ Similar studies revealed a relationship between electrical workers exposed to EMF and increased risk for leukemia. ${ }^{26}$ In the blood analyses of the electrical workers

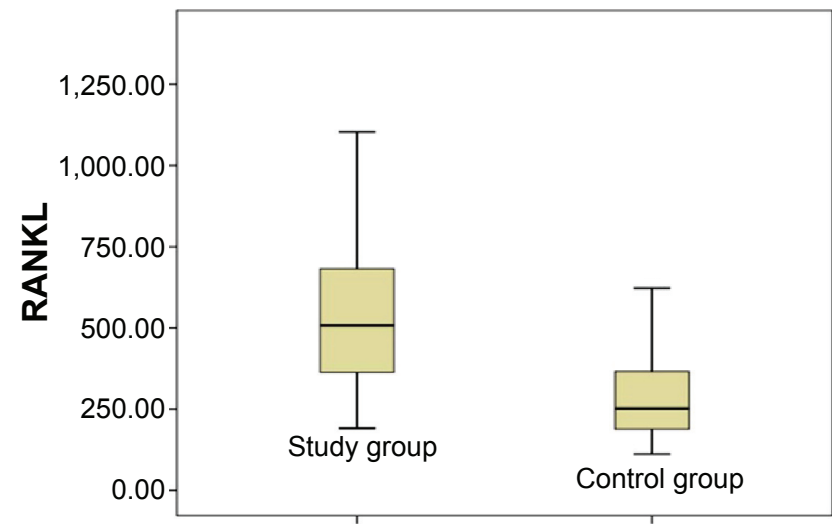

Figure 2 Distribution of RANKL values in the study and control groups. 


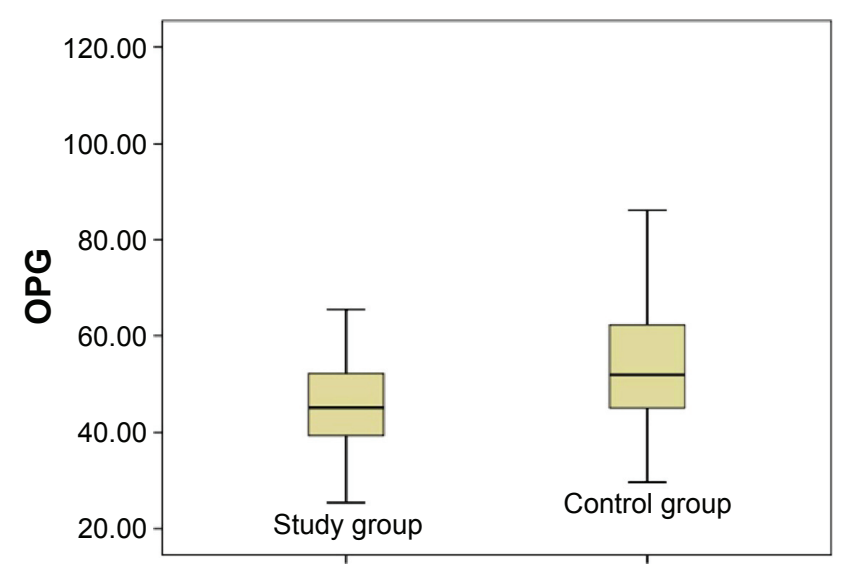

Figure 3 Distribution of OPG values in the study and control groups. Abbreviation: OPG, osteoprotegerin.

in the present study, an increase in $\mathrm{Ca}, \mathrm{P}$, and oxidative stress levels and a decrease in antioxidant enzyme activities were detected. We believe that such effects which were observed on electrical workers who are exposed to high EMF even in breaks might have been caused by spending a significant part of their shift in substations and high-voltage transmission lines.

Important health problems of the present day include osteoporosis, fractures, and stress fractures. In bone DEXA scans, mean BMD measures of L1-L4 lumbar vertebrae and femur as well as ALP and P levels were observed significantly higher in the study group than the control group. Moreover, levels of RANK, RANKL, and OPG support the idea that a strong predisposition for osteoporosis may increase for those working around HVETL. In comparison between the experimental and control groups, bone loss was found to be resulted from the EMF exposure and not from age. These results indicate that bone damage may increase due to the EMF exposure.

Experiments on mice indicated that bone density and volume decrease, osteoporosis progressing with fractures

Table 4 Comparison of thyroid function tests and thyroid's diameter measurements between groups

\begin{tabular}{llll}
\hline $\begin{array}{l}\text { Measured } \\
\text { parameters }\end{array}$ & $\begin{array}{l}\text { Control } \\
\text { group }\end{array}$ & $\begin{array}{l}\text { Study } \\
\text { group }\end{array}$ & P-value \\
\hline FT3, mean \pm SD & $3.34 \pm 0.32$ & $3.22 \pm 0.5 I$ & $0.302^{*}$ \\
FT4, mean \pm SD & $I .21(0.92-2.67)$ & $I(0-3.19)$ & $<\mathbf{0 . 0 0 I * *}$ \\
TSH & $1.66(0.48-4.34)$ & $1.41(0.0 I-7.72)$ & $0.180^{* *}$ \\
RapD & $16.15(12.5-24)$ & $18(8-37)$ & $0.056^{* *}$ \\
LapD & $15.6(12.1-24.3)$ & $17(10-30)$ & $\mathbf{0 . 0 3 7 * *}$ \\
Istmus D & $3.35(2.20-5.9)$ & $3.3(1-13)$ & $0.647^{* *}$ \\
\hline
\end{tabular}

Notes: *Independent $t$-test and **Mann-Whitney $U$-test was applied. The data were presented as median (minimum-maximum) unless stated otherwise. Bold $P$-value shows the difference was statistically significant $(P<0.05)$.

Abbreviations: RapD, right anteroposterior diameter; LapD, left anteroposterior diameter; Istmus D, tiroid istmus diameter; TSH, thyroid-stimulating hormone; FT3, free triiodothyronine; FT4, free thyroxine; TSH, thyroid-stimulating hormone; SD, standard deviation.
Table 5 Comparison LI-L4 and femoral BMD values with the DEXA results as per study group's ages

\begin{tabular}{lllll}
\hline Bone type & Age (years) & $\mathbf{N}$ & T-score & P-value \\
\hline LI-L4 & $20-29$ & 4 & $-1.35 \pm 0.65$ & \\
& $30-39$ & 24 & $-0.97 \pm 0.53$ & 0.504 \\
& $40-49$ & 15 & $-1.28 \pm 0.57$ & 0.904 \\
\multirow{4}{*}{ Femur } & 50 and older & 4 & $-1.28 \pm 0.62$ & 0.918 \\
& $20-29$ & 4 & $-1.02 \pm 0.5 \mathrm{I}$ & \\
& $30-39$ & 24 & $-0.39 \pm 0.48$ & 0.167 \\
& $40-49$ & 15 & $-0.88 \pm 0.58$ & 0.770 \\
& 50 and older & 4 & $-0.78 \pm 0.34$ & 0.674 \\
\hline
\end{tabular}

Note: Independent $t$-test was applied. The data were given as mean \pm standard deviation.

Abbreviations: BMD, bone mineral density; DEXA, dual-energy $X$-ray absorptiometry; $t$-test, independent samples $t$-test.

and deformities appear in the absence of OPG, ${ }^{27,28}$ and osteoporosis is reversed by intravenous OPG injection. ${ }^{29}$ Osteopetrosis characterized with osteoclastogenesis was observed on the mice of which genetic structure of OPG was modified..$^{30}$ These data show that OPG is necessary to preserve the bone mass physiologically. RANKL, which is an agent stimulating the dendritic cells, acts as a life factor for mature $\mathrm{T}$ cells and regulates proliferations. ${ }^{31,32}$ Such activities were observed to be dependent to the activation of RANKL by binding to membrane receptor RANK. ${ }^{33}$ Similar approaches with OPG were tried to understand the role of RANKL in the bone metabolism. Despite OPG, severe osteoporosis was observed on the mice with genetically modified RANKL; ${ }^{8}$ complete disappearance of osteoclasts and development of osteoporosis were observed in the mice without RANKL. ${ }^{34,35}$ According to these data, OPG is a strong bone protective agent, whereas RANKL is a preresorptive factor. In vitro trials also seem to support the in vivo data. ${ }^{34-37}$ Although there are studies indicating that lowfrequency EMF provides an increase on recovery of bone fractures and BMD in the literature, ${ }^{38-41}$ therapeutic doses of EMWs for osteoporosis were only observed when they were applied in pulses with low doses of $15-72 \mathrm{~Hz} .{ }^{42}$ Longterm occupational exposure to EMWs in higher doses has

Table 6 Comparison LI-L4 and femoral BMD values with the DEXA results according to work experience

\begin{tabular}{lllll}
\hline Bone type & Work experience (years) & $\mathbf{N}$ & T-score & P-value \\
\hline LI-L4 & $10-19$ & 32 & $-1.02 \pm 0.55$ & $0.255^{*}$ \\
& 20 and older & 15 & $-1.36 \pm 0.76$ & \\
Femur & $10-19$ & 32 & $-0.44 \pm 0.28$ & $\mathbf{0 . 0 2 \mathbf { I } ^ { * }}$ \\
& 20 and older & 15 & $-0.94 \pm 0.5 \mathrm{I}$ &
\end{tabular}

Notes: *Independent $t$-test was applied. Bold $P$-value defines the significant difference $(P<0.05)$. The data were given as mean \pm standard deviation.

Abbreviations: BMD, bone mineral density; DEXA, dual-energy $X$-ray absorptiometry. 
Table 7 Comparison of the bone biochemistry parameters according to work experience

\begin{tabular}{lllll}
\hline $\begin{array}{l}\text { Biochemistry } \\
\text { parameters }\end{array}$ & $\begin{array}{l}\text { Work experience } \\
\text { (years) }\end{array}$ & $\mathbf{N}$ & Mean & P-value \\
\hline $\mathrm{Ca}$ & $10-19$ & 32 & $9.27 \pm 0.27$ & $0.872^{*}$ \\
& 20 and older & 15 & $9.29 \pm 0.50$ & \\
$\mathrm{P}(\mathrm{mg} / \mathrm{dL})$ & $10-19$ & 32 & $2.85 \pm 0.44$ & $0.28 I^{*}$ \\
& 20 and older & 15 & $2.71 \pm 0.31$ & \\
$\mathrm{ALP}(\mathrm{U} / \mathrm{L})$ & $10-19$ & 32 & $84.93 \pm 13.63$ & $\mathbf{0 . 0 4 4}$ \\
& 20 and older & 15 & $94.67 \pm 23.63$ & \\
Creatine $(\mathrm{mg} / \mathrm{dL})$ & $10-19$ & 32 & $0.90 \pm 0.11$ & $0.69 *$ \\
& 20 and older & 15 & $0.89 \pm 0.08$ & \\
RANK (pg/mL) & $10-19$ & 32 & $96.89 \pm 41.96$ & $0.182^{*}$ \\
& 20 and older & 15 & $113.56 \pm 82.20$ & \\
RANKL (pmol/L) & $10-19$ & 32 & $391.33 \pm 109.84$ & $0.166^{*}$ \\
& 20 and older & 15 & $443.78 \pm 168.88$ & \\
\hline
\end{tabular}

Notes: *Independent $t$-test was applied. Bold $P$-value defines the significant difference $(P<0.05)$. The data were given as mean \pm standard deviation.

Abbreviations: ALP, alkaline phosphatase; $\mathrm{P}$, phosphor.

a reverse effect. Atay et $\mathrm{a}^{42}$ detected a significant decrease in BMD levels in the iliac wing area where mobile phones with $900-1,800 \mathrm{MHz}$ are carried when compared with the other side in their study. Similarly, Cidem et al reported a decrease in bone density of the forearm which are used by the mobile phone owners while holding the phone. ${ }^{43}$ Kunt and Dayığlu and Kunt et al found in their study conducted on the radiology employee that the lowest densitometry level was in MRI employee. ${ }^{44,45}$

In the clinical trials reporting the preventive effect for osteoporosis and increase of BMD, treatment protocols applied to the study groups are dependent on the principle of application of a certain EMW dose for a certain period. In other words, a doze of exposure is certain and may be limited. However, a decrease in femoral and lumbar BMD levels of the electrical workers was met. This is contrary to the protective effect of low-frequency EMWs on bone metabolism. Possible factors include dose of the magnetic field exposed and duration of exposure. Although the effect of low-frequency EMWs to prevent osteoporosis was brought into the forefront in the literature, long-term exposure to the magnetic field around HVETL may cause a hazardous effect in the bone metabolism rather than a protective effect and creates an effect which is similar to those by devices creating high-frequency EMF such as cell phones. From this point of view, we believe that low-dose EMFs may have a therapeutic effect, whereas long-term and high-dose EMWs have a destructive effect on the BMD.

Effects of low-frequency EMWs of which electrical workers who are exposed to electromagnetic radiation most is not like the effects of a high-frequency EMWs. No temperature increase was detected in the temperature measurements performed on the electrical workers. Therefore, heat-dependent effects such as MRI devices creating highEMWs are not observed in electrical workers. However, the exposure of these individuals to low-frequency EMWs intermittently for a long period, in other words, the effects of chronic exposure may appear after years. The reason for that is the inability of the organism to repair the damage until next exposure and accumulation of the damages for exposures to repetitive EM radiation, even in low frequencies.

Besides studies reporting that EMF activates the formation and growth of the bones, inhibits osteoblastic activity, provides contribution to the healing of the bone fractures, and affects the granulation of formation of fibrous tissues in the wound healing; ${ }^{46,47}$ some studies demonstrated that biological effects of the low-frequency at the cellular level include creating change at the levels of proliferation and differentiation, ${ }^{48,49}$ changes at the levels of messenger ions such as $\mathrm{Ca}^{2+}, 50,51$ and creating changes in the shape and format of the cells. ${ }^{52,53}$ Studies conducted about the effects of EMFs on the bone formation and fracture healing report different mechanism of action. In these studies, the mechanisms of action have been explained as the osteogenesis-stimulating mechanism, ${ }^{54-58}$ and physiological and physical effects on the bone metabolism and cellular processes. Furthermore, it has been reported that EMF has effects on the calcium channels, intracellular ionized calcium changes, receptor behavior and genes, and that EMF increases the synthesis and transcription of deoxyribonucleic acid (DNA), intercellular calcium and the synthesis of messenger ribonucleic acid of type-I collagen, stimulating the production of extracellular

Table 8 Comparison of serum oxidative stress index between groups

\begin{tabular}{llll}
\hline Oxidative stress parameters & Control group & Study group & P-value \\
\hline TAS $($ mmol Trolox Equiv/L) & $1.93(0.40-3.73) 0.84$ & $1.62(0.16-3.96)$ & $\mathbf{0 . 0 1 7 ^ { * * }}$ \\
TOS $\left(\mu \mathrm{mol} \mathrm{H} \mathrm{O}_{2}\right.$ equiv/L) & $7.63 \pm 3.10$ & $9.39 \pm 3.68$ & $\mathbf{0 . 0 1 3 ^ { * }}$ \\
OSI $(\mathrm{AU})$ & $487.82 \pm 462.29$ & $957.32 \pm 1,201.97$ & $\mathbf{0 . 0 1 3 ^ { * }}$ \\
\hline
\end{tabular}

Notes: *Independent $t$-test, **Mann-Whitney $U$-test. Data are median (minimum-maximum) unless otherwise indicated. Bold $P$-value defines the significant difference $(P<0.05)$.

Abbreviations: TAS, total antioxidant status; TOS, total oxidant status; OSI, oxidative stress index. 
matrix. ${ }^{56,58}$ According to all of these results, further radiologic, biochemical, and histopathologic studies are needed to demonstrate the effects of the low- and high-frequency EMFs on the bone tissues and fracture healing as well as to clarify EMFs' mechanisms of action.

Many studies were carried out for the effect of EMF to thyroid hormone synthesis and different results were reported. In a large-scale study, Bergamaschi et al detected no significant difference on the workers exposed to EMF because of cell phone use in terms of the TSH level; ${ }^{59}$ Selmaoui et al found that low-dose EMF exposure for every other night or continuously did not affect serum total-free thyroxin (T4) and triiodothyronine (T3) as well as TSH levels. ${ }^{60}$ No significant effect of low-dose EMF exposure for a long period was found on TSH in human studies carried out in a similar manner with less participation, ${ }^{61,62}$ whereas no difference was detected on individuals exposed to low-density EMF for a long period in terms of the frequency of thyroid cancer. ${ }^{63}$ Koyu et al found a significant decrease in T3, T4, and TSH levels in the rats who were exposed to a low-dose EMF for 4 weeks when compared with the control group. ${ }^{64}$ Another study carried out with rats detected a significant decrease in serum thyroid hormone levels as a result of low-dose EMF exposure for a long period in comparison with the control group. ${ }^{65,66}$ De seze et al detected on volunteer males that cell phone use for 2 hours a day for one month reduced TSH levels by $21 \% .{ }^{67}$

A positive correlation was shown between the effect of radiation on different endocrine organs and radiation dose and exposure duration. ${ }^{68}$ Low TSH levels were shown more frequent in those with longer duration of exposure to EMF and duration of talking with cell phone, ${ }^{46}$ whereas some studies showed an increase in thyroid hormone and TSH levels as a result of long-term exposure to EMF of rats. ${ }^{69,70}$ In the present study, we found FT4 levels significantly lower in the workers who are exposed to EMF for a long period, and no significant difference in FT3 and TSH levels were detected. Although a low dose causes a decrease in T4, it may depend on long-term exposure to EMF. Moreover, more nodules were observed in the study group in percentage when compared to the normal population, but no statistically significant difference was detected. In the comparison for gland sizes, a significant increase was detected in the dimensions of the left lobe particularly in the study group than the control group. Rajkovic et al detected an increase in the volume density of thyroid follicles histologically on the rats exposed to a low-dose EMF for 3 months. ${ }^{65}$
Exposure to ionizing radiation increases the risk of benign or malign nodule. Palpable thyroid nodules are detected in $20 \%-30 \%$ of the population affected by radiation. ${ }^{71}$ However, there is not any study which investigates the effect of electromagnetic radiation on the thyroid gland in the literature. In the present study, occupational higher electromagnetic radiation is not confronted as a significant risk factor statistically in terms of thyroid nodule frequency and parenchyma echogenicity. Nevertheless, the increase in the gland sizes is statistically significant.

\section{Conclusion}

One of the occupational groups who are exposed to electromagnetic radiation most is electrical workers. The electrical workers who are exposed to EMF radiation caused by high-voltage transmission lines and transformers for a long period were observed to complain about general indisposition, exhaustion, apathy, anxiety, and headache. Furthermore, a decrease in BMD, serum ALP, $\mathrm{Ca}, \mathrm{P}, \mathrm{RANK}, \mathrm{RANKL}$, and antioxidant enzyme levels as well as an increase in oxidative stresses and OPGs were observed. Consequently, it was observed that the balance between construction and destruction in the bone metabolism of the electrical workers who are employed in HVETL replaced toward destruction and led to a decrease in OPG levels and an increase in RANK and RANKL levels. In line with the previous studies reporting that long-term exposure to an EMF causes disorders in many organs and systems, it is considered that long-term exposure to an EMF affects bone and thyroid metabolism and also increases OSI by increasing the TOS and decreasing the antioxidant status.

Periodical investigations, EMF measurements around the workplaces, and raising awareness of the electrical workers about these exposures should be done to detect possible negative impacts on the electrical workers who are exposed to electromagnetic radiation.

The present study has some limitations. The first limitation is that the majority of the employees had not any thyroid USS before and were not aware of the nodule during the study. The second limitation is the requirement of new studies including more electrical workers to obtain more reliable data.

\section{Acknowledgments}

This study was supported by Afyon Kocatepe University Scientific Research Projects Unit (Project no: 12.TIP.11). Halil Kunt, Ihsan Senturk and Yucel Gonul shared first 
authorship of this paper. This manuscript was a poster presentation at the XXIV International Symposium on Morphological Sciences in Istanbul on September 2-6, 2015, Turkey.

\section{Disclosure}

The authors report no conflicts of interest in this work.

\section{References}

1. Şeker S, Çerezci O. Radyasyon Kuşatması. İstanbul: Boğaziçi Üniversitesi Yayınevi matbaası; 2000.

2. Bold A, Toros H, Şen O. Manyetik alanın insan sağlığı üzerindeki etkisi. III. Atmosfer Bilimleri Sempozyumu, 19-21 Mart, İTÜ, İstanbul; 2003.

3. Panagopoulos DJ, Karabarbounis A, Margaritisa LH. Mechanism for action of electromagnetic fields on cells. Biochem Biophys Res Commun. 2002;298:95-102.

4. Çolak İ, Koşanay İ. TV Vericilerinden Kaynaklanan RF Elektromanyetik Kirliliğin Tahmininde Yapay Sinir Ağlarının Etkinliği. 5. Uluslararası İleri Teknolojiler Sempozyumu, Karabük; 2009.

5. Taktak F, Tiryakioğlu İ, Yılmaz İ. GSM'de Kullanılan Elektromanyetik Dalgaların İnsan Sağlığına Etkilerinin İrdelenmesi. İstanbul Teknik Üniversitesi, 2. Mühendislik Ölçmeleri Sempozyumu; İstanbul; 2005.

6. Havas M. Biological effects of low frequency electromagnetic fields. In: Clements-Croome D, editor. Electromagnetic Environments and Health in Buildings. London: Spon Press; 2004:207-232.

7. Seze R, Peray PF, Miro L. GSM radiocellular telephones do not disturb to secretion of antepituitary hormones in humans. Bioelectromagnetics. 1998;29:271-278.

8. Seyhan N. Elektromanyetik Kirlilik ve Sağlı̆̆ımız. Nöropsikiyatri Dergisi. 2010;47:158-161.

9. BioInitiative 2012. A Rationale for Biologically-based Public Exposure Standards for Electromagnetic Fields. The BioInitiative 2012; Report. Available from: http://www.bioinitiative.org. Accessed December 21, 2015.

10. Roda-Murillo O, Roda-Moreno JA, Morente-Chiquero MT. Effects of low-frequency magnetic fields on different parameters of embryo of Gallus domesticus. Electromagn Biol Med. 2005;24:55-62.

11. Frahm J, Lantow M, Lupke M, Weiss DG, Simkó M. Alteration in cellular functions in mouse macrophages after exposure to $50 \mathrm{~Hz}$ magnetic fields. J Cell Biochem. 2006;99:168-177.

12. Güler G, Seyhan N, Arcioğlu A. Effects of static and $50 \mathrm{~Hz}$ alternating electric fields on superoxide dismutase activity and TBARS levels in guinea pigs. Gen Physiol Biophys. 2006;25:177-193.

13. Güler G, Turkozer Z, Tomruk A, Seyhan N. The protective effects of N-acetyl-L-cysteine and epigallocatechin-3-gallate on electric field-induced hepatic oxidative stres. Int J Radiat Biol. 2008;84: 669-680.

14. Tohumoglu G, Canseven AG, Cevik A, Seyhan N. Formulation of ELF magnetic fields effects on malondialdehyde level and myloperoxidase activity in kidney using genetic programming. Comput Methods Programs Biomed. 2007;86:1-9.

15. Canseven AG, Coşkun S, Seyhan N. Effects of various extremely low frequency magnetic fields on the free radical processes, natural antioxidant systemand respiretory burst system activities in the heart and liver tissues. Indian J Biochem Biophys. 2008;45:326-331.

16. Van Wijngaarden E, Savitz DA, Kleckner RC, Cai J, Loomis D. Exposure to electromagnetic fields and suicide among electric utility workers: a nested case-control study. Occup Environ Med. 2000;57: 258-263.

17. Yamazaki S, Sokejima S, Mizoue T, et al. Association between high voltage overhead transmission lines and mental health: a crosssectional study. Bioelectromagnetics. 2006;27:473-478.

18. Draper G, Vincent T, Kroll ME, Swanson J. Childhood cancer in relation to distance from high voltage power lines in England and Wales: a case-control study. BMJ. 2005;330:1290-1295.
19. Baltas CS, Balanika AP, Raptou PD. Clinical practice guidelines proposed by the Hellenic Foundation of Osteoporosis for the management of osteoporosis based on DXA results. J Musculoskelet Neuronal Interact. 2005;5:388-392.

20. Chang K, Chang WHS, Huang S, Huang S, Shih C. Pulsed electromagnetic fields stimulation affects osteoclast formation by modulation of osteoprotegerin. RANK ligand and macrophage colony-stimulating facto. J Orthopaedic Res. 2005;23:1308-1314.

21. ICNIRP. EMF guidelines. Health Physics 1998;74:494-522.

22. Zaffanella LE, Kalton GW. Survey of Personal Magnetic Field Exposure Phase II:1000-Person Survey EMFRAPID Program Engineering Project 6. Oak Ridge, TN: Lockheed Martin Energy Systems, Inc.; 1998.

23. Canseven AG, Seyhan N, Aydın A, Çevik C, Işımer A. Effects of ambient ELF magnetic fields: variations in electrolyte levels in the brain and blood plasma. Gazi Med J. 2005;16:121-127.

24. Ahlbom A, Day N, Feychting M, et al. A pooled analysis of magnetic fields and childhood leukaemia. Br J Cancer. 2000;83:692-698.

25. Schüz J, Grigat JP, Brinkmann K, Michaelis J. Residential magnetic fields as a risk factor for childhood acute leukaemia: results from a German population-based case-control study. Int J Cancer. 2001;91:728-735.

26. Bethwaite P, Cook A, Kennedy J, Pearce N. Acute leukemia in electrical workers: a New Zealand case-control study. Cancer Causes Control. 2001;12:683-689.

27. Bucay N, Sarosi I, Dunstan CR, et al. Osteoprotegerin-deficient mice develop early onset osteoporosis and arterial calcification. Genes Dev. 1998; 12:1260-1268.

28. Yun TJ, Tallquist MD, AicherA, et al. Osteoprotegerin, a crucial regulator of bone metabolism, also regulates B cell development and function. J Immunol. 2001;166:1482-1491.

29. Min H, Morony S, Sarosi I, et al. Osteoprotegerin reverses osteoporosis by inhibiting endosteal osteoclasts and prevents vascular calcification by blocking a process resembling osteoclastogenesis. J Exp Med. 2000; 192:463-474.

30. Simonet WS, Lacey DL, Dunstan CR. Osteoprotegerin: a novel secreted protein involved in the regulation of bone density. Cell. 1997; 89:309-319.

31. Anderson DM, Maraskovsky E, Billingsley WL, et al. Ahomologue of the TNF receptor and its ligand enhance T-cell growth and dendritic-cell function. Nature. 1997;390:175-179.

32. Wong BR, Josien R, Lee SY, et al. TRANCE (tumor necrosis factor (TNF)-related activation-induced cytokine), a new TNF family member predominantly expressed in T cells, is a dendritic cell-specific survival factor. J Exp Med. 1997;186:2075-2080.

33. Wong BR, Josien R, Lee SY, Vologodskaia M, Steinman RM, Choi Y. The TRAF family of signal transducers mediates NF-kappa B activation by the TRANCE receptor. J Biol Chem. 1998;273:28355-28359.

34. Fata JE, Kong YY, Li J, et al. The osteoclast differentiation factor osteoprotegerin-ligand is essential for mammary gland development. Cell. 2000;103:41-50.

35. Kong YY, Feige U, Sarosi I, et al. Activated T cells regulate bone loss and joint destruction in adjuvant arthritis through osteoprotegerin ligand. Nature. 1999;402:304-309.

36. Burgess TL, Qian Y, Kaufman S, et al. The ligand for osteoprotegerin (OPGL) directly activates mature osteoclasts. J Cell Biol. 1999;145: 527-538.

37. Darnay BG, Haridas V, Ni J, Moore PA, Aggarwal BB. Characterization of the intracellular domain of receptor activator of NFkappaB (RANK). Interaction with tumor necrosis factor receptor-associated factors and activation of NF-kappab and c-Jun N-terminal kinase. J Biol Chem. 1998;273:20551-20555.

38. Chang K, Chang WH. Pulsed electromagnetic fields prevent osteoporosis in an ovariectomized female rat model, a prostaglandin E2-associated process. Bioelectromagnetics. 2003;24:189-198.

39. Sert C, Mustafa D, Duz MZ. The preventive effect on bone loss of $50-\mathrm{Hz}, 1-\mathrm{mT}$ electromagnetic field in ovariectomized rats. J Bone Miner Metab. 2002;20:345-349. 
40. Garland DE, Adkins RH, Matsuno NN. The effect of pulsed electromagnetic fields on osteoporosis at the knee in individuals with spinal cord injury. J Spinal Cord Med. 1999;22:239-245.

41. Bilotta TW, Zati A, Gnudi S. Electromagnetic fields in the treatment of postmenopausal osteoporosis, an experimental study conducted by densitometric, dry ash weight and metabolic analysis of bone tissue. Chir Organi Mov. 1994;79:309-313.

42. Atay T, Aksoy BA, Aydogan NH, Baydar ML, Yildız M, Ozdemir R. Effect of electromagnetic field induced by radio frequency waves at 900 to $1,800 \mathrm{MHz}$ on bone mineral density of iliac bone wings. J Craniofac Surg. 2009;20:1556-1560.

43. Cidem M, Bahadir C, Karakoc Y, Karacan I. Forearm bone mineral density in healthy young adult mobile phone users. Med Sci. 2012; $1: 35-40$.

44. Kunt H, Dayığlu H. The effects of radiation on bone mineral density of radiology workers depending on the device they use. Eur J General Med. 2011;8:318-322.

45. Kunt H, Dayığlu H, Çaycı MK, Korkmaz M. The assessment as bone mineral density of bone damage in radiology workers occupationally exposed to ionizing radiation. Eur J General Med. 2013;10:214-218.

46. Ciombor DM. The role of electrical stimulation in bone repair. Foot Ankle Clin. 2005;10:579-593.

47. Wu H. Effect of electromagnetic fields on proliferation and differentiation of cultured mouse bone marrow mesenchymal stem cells. J Huazhong Univ Sci Technolog Med Sci. 2005;2:185-187.

48. Goodman R, Blank M. Insights into electromagnetic interaction mechanisms. J Cell Physiol. 2002;192:16-22.

49. Marmi V, Lisi A, Rieti S, et al. Low electromagnetic field $(50 \mathrm{~Hz})$ induces differentiation on primary human oral keratinocytes (HOK). Bioelectromagnetics. 2004;25:118-126.

50. Wei M, Guizzetti M, Yost M, Costa LG. Exposure to 60-Hz magnetic fields and proliferation of human astrocytoma cells in vitro. Toxicol Appi Pharmacol. 2000;162:166-176.

51. Aldinucci C, Palmi M, Sgaragli G, et al. The effect of pulsed electromagnetic fields on the physiologic behaviour of a human astrocytoma cell line. Biochim Biophys Acta. 2000;1499:101-108.

52. Manni V, Lissi A, Pozzi D, et al. Effects of extremely low frequency $(50 \mathrm{~Hz})$ magnetic field on morphological and biochemical properties of human keratinocytes. Bioelectromagnetics. 2002;23:298-305.

53. Pessina GP, Aldinucci C, Palmi M, et al. Pulsed electromagnetic fields affect the intracellular calcium concentrations in human astrocytoma cells. Bioelectromagnetics. 2001;22:503-510.

54. Ryaby JT. Clinical effects of electromagnetic and electric fi elds on fracture healing. Clin Orthop Relat Res. 1998;355:205-215.

55. Ciombor DM, Aaron RK. The role of electrical stimulation in bone repair. Foot Ankle Clin. 2005;10:579-593.

56. Leisner S, Shahar R, Aizenberg I, et al. The effect of shortduration, high-intensity electromagnetic pulses on fresh ulnar fractures in rats. J Vet Med A: Physiol Pathol Clin Med. 2002;49:33-37.
57. Spadaro JA, Bergstrom WH. In vivo and in vitro effects of a pulsed electromagnetic field on net calcium flux in rat calvarial bone. Calcif Tissue Int. 2002;70:496-502.

58. Shupak NM, Prato FS, Thomas AW. Therapeutic uses of pulsed magnetic-field exposure: a review. Radio Sci Bull. 2003;307:9-32.

59. Bergamaschi A, Magrini A, Ales G, Coppeta L, Somma G. Are thyroid dysfunctions related to stress or microwave exposure $(900 \mathrm{MHz})$ ? Int J Immunopathol Pharmacol. 2004;17:31-36.

60. Selmaoui B, Lambrozo J, Touitou Y. Endocrine functions in young men exposed for one night to a $50-\mathrm{Hz}$ magnetic field. A circadian study of pituitary, thyroid and adrenocortical hormones. Life Sci. 1997; 61:473-486

61. Djeridane Y, Touitou Y, de Seze R. Influence of electromagnetic fields emitted by GSM-900 cellular telephones on the circadian patterns of gonadal, adrenal and pituitary hormones in men. Radiat Res. 2008; 169:337-343.

62. Dahmen N, Ghezel-Ahmadi D, Engel A. Blood laboratory findings in patients suffering from self-perceived electromagnetic hypersensitivity (EHS). Bioelectromagnetics. 2009;30:299-306.

63. Lope V, Pérez-Gómez B, Aragonés N. Occupational exposure to ionizing radiation and electromagnetic fields in relation to the risk of thyroid cancer in Sweden. Scand J Work Environ Health. 2006;32:276-284.

64. Koyu A, Gökalp O, Özgüner F, et al. The effects of subchronic $1800 \mathrm{MHz}$ electromagnetic field exposure on the levels of TSH, T3, T4, cortisol and testosterone hormones. Journal of General Medical. 2005; $15: 101-105$

65. Rajković V, Matavulj M, Lukac T, Gledić D, Babić L, Lazetić B. Morphophysiological status of rat thyroid gland after subchronic exposure to low frequency electromagnetic field. Med Pregl. 2001;54:119-127.

66. Zagorskaya EA, Rodina GP. Responses of the endocrine system and peripheral blood of rats to single and chronic effects of a pulsed low frequency electromagnetic field. Kosm Biol Aviokosm Med. 1990;24: 56-60.

67. De seze R, Peray PF, Miro L. GSM radiocellular telephones do not disturb the secretion of antepituitary hormones in humans. Bioelectromagnetics. 1998;19:271-278.

68. Moustafa YM, Moustafa RM, Belacy A, Abou-El-Ela SH, Ali FM. Effects of acute exposure to the radiofrequency fields of mobile phones on plasma lipid peroxidase and antioxidase activities in human erythrocytes. J Pharmaceut Biomed Anal. 2001;26:605-608.

69. Udintsev NA, Serebrov VY, Tsyrov GI. Vliyanie peremennogo magnetnogo polya promyshlenoj chastity na funktsionalnoe sostoyanie shchitovidnoj zhelezi i pogloshehenie tiroksina organamikrys. Bull Exp Biol Med. 1978;86:544-546.

70. Lu ST, Lebda N, Michaelson SM, Pettit S. Serum-thyroxine levels in microwave-exposed rats. Radiat Res. 1985;101:413-423.

71. Favus AB, Schineder AB. Thyroid cancer occuring as a late consequence head and neck irradiation. NEJM. 1976;294:1019-1025.
OncoTargets and Therapy

\section{Publish your work in this journal}

OncoTargets and Therapy is an international, peer-reviewed, open access journal focusing on the pathological basis of all cancers, potential targets for therapy and treatment protocols employed to improve the management of cancer patients. The journal also focuses on the impact of management programs and new therapeutic agents and protocols on
Dovepress

patient perspectives such as quality of life, adherence and satisfaction. The manuscript management system is completely online and includes a very quick and fair peer-review system, which is all easy to use. Visit http://www.dovepress.com/testimonials.php to read real quotes from published authors. 